\title{
ANALISIS KETERSEDIAAN BAHAN BAKU TERHADAP INDUSTRI PENGOLAHAN IKAN TUNA DI PT. PERMATA MARINDO JAYA JAKARTA
}

\author{
Afif Gunadi, Urip Rahmani \\ Fakultas Perikanan dan Ilmu Kelautan \\ Universitas Satya Negara Indonesia, Jakarta
}

\begin{abstract}
ABSTRAK
Penelitian ini bertujuan untuk mengetahui jenis serta bahan baku yang digunakan dalam proses pengolahan tuna di PT Permata Marindo Jaya (PT PMJ) dan menganalisis ketersediaan bahan baku yang terdapat di coldstorage PT Permata Marindo Jaya (PT PMJ). Adapun latar belakang penulisan karya ilmiah ini karena nilai ekspor PT PMJ sangat bergantung pada permintaan pasar yang sering berubah, Oleh karena itu, perusahaan harus selalu memiliki persediaan bahan baku yang diperlukan dalam proses produksi. Dalam mengendalikan ketersediaan bahan baku, PT PMJ masih menggunakan metode manual yang belum optimal dalam menyediakan bahan baku untuk proses industri. Untuk meminimalisir biaya persediaan Economic Order dapat di Quantity".Metode EOQ berusaha mencapai tingkat persediaan yang seminimum mungkin biaya rendah dan mutu lebih baik. Perencanaan metode EOQ dalam suatu perusahaaan akan mampu meminimalisasi terjadinya out of stock sehingga tidak mengganggu proses dalam perusahaan dan mampu menghemat biaya persediaan yang dikeluarkan oleh perusahaan karena adanya efisisensi persediaan bahan baku di dalam perusahaan yang bersangkutan. Hasil penelitian ini adalah PT PMJ menggunakan jenis bahan baku tuna Big eye dan Yellow fin yang didapat dari PT Charly Wijaya Tuna dan TLC (Tuna Landing Center). Total biaya persediaan dengan metode Economic Order Quantity (EOQ) lebih efisien dibandingkan dengan metode yang digunakan PT. PMJ.
\end{abstract}

Kata Kunci: PT PMJ (PT Permata Marindo Jaya), EOQ (Economic Order Quantity), TLC (Tuna Landing Center)

\section{PENDAHULUAN}

Nilai ekspor PT Permata Marindoo Jaya sangat bergantung pada permintaan pasar yang sering berubah, Oleh karena itu, perusahaan harus selalu memiliki persediaan bahan baku yang 
diperlukan dalam proses produksi. Pengendalian ketersediaan bahan baku pada PT PMJ masih menggunakan metode manual yang belum optimal dalam menyediakan bahan baku untuk proses industri. Untuk meminimalisir biaya persediaan dapat digunakan analisisEconomic Order“ Quantity”.

Metode EOQ berusaha mencapai tingkat persediaan yang seminimum mungkin biaya rendah dan mutu lebih baik. Perencanaan metode EOQ dalam suatu perusahaaan akan mampu meminimalisasi terjadinya out of stock sehingga tidak mengganggu proses dalam perusahaan dan mampu menghemat biaya persediaan yang dikeluarkan oleh perusahaan karena adanya efisisensi persediaan bahan baku di dalam perusahaan yang bersangkutan.

Tujuan penelitian ini adalah (1) Untuk mengetahui jenis serta asal bahan baku yang digunakan dalam proses pengolahan tuna di PT Permata Marindo Jaya (PT PMJ) dan (2) Menganalisis ketersediaan bahan baku yang terdapat di coldstorage PT Permata Marindo Jaya (PT PMJ). Penelitian dilaksanakan Pada Bulan Agustus Sampai Bulan Oktober 2017, di PT Permata Marindo Jaya yang berada didalam kawasan Pelabuhan Perikanan Samudera Nizam Zachman Jakarta yang berlokasi di Jalan Hiu Raya Blok D No 4, Penjaringan, Jakarta Utara, Provinsi DKI Jakarta.

\section{METODOLOGI}

Jenis penelitian ini adalah deskriptif (descriptive research) dengan pendekatan kualitatif, yaitu untuk mendeskripsikan Ketersediaan bahan baku terhadap industri pengolahan ikan di PT Permata Marindo Jaya Jakarta.

Analisis data Jenis dan asal ketersediaan bahan baku produk tuna beku serta penentuan faktor-faktor yang mempengaruhi ketersediaan bahan baku dianalisis secara deskriptif. Pengendalian ketersediaan bahan baku tuna di PT. Permata Marindo Jaya Jakarta memakai parameter-parameter yang diketahui secara pasti dianalisis menggunakan rumus Heizer \& Render (2001) sebagai berikut:

$\mathrm{EOQ}=\frac{\sqrt{2}}{}$

Dimana : 
$\mathrm{EOQ}=$ Jumlah optimal barang per pemesanan $\left(\mathrm{Q}^{*}\right)(\mathrm{Kg})$

$\mathrm{D}=$ Permintaan tahunan barang persediaan dalam unit $(\mathrm{Kg})$

$\mathrm{S}=$ Biaya pemasangan atau pemesanan setiap pesanan $(\mathrm{Rp})$

$\mathrm{H} \quad$ = Biaya penahan atau penyimpanan per unit per tahun

$\mathrm{Q} \quad=$ Banyaknya unit setiap kali pemesanan $(\mathrm{Kg})$

terdapat beberapa rumus untuk mendukung perhitungan biaya persediaan, antara lain:

a. Persediaan rata-rata yang tersedia $=-$

b. Jumlah pemesanan yang diperkirakan $=-$

c. Biaya pemesanan tahunan $=-$

d. Biaya penyimpanan tahunan $=-$

e. Biaya Pembelian $=$ Harga per unit $\times \mathrm{D}$

f. Total Biaya Persediaan = Biaya pembelian + Biaya pemesanan tahunan + Biaya penyimpanan tahunan

\section{PEMBAHASAN}

Jenis Bahan Baku dan Asal Ketersediaan Jenis yang digunakan untuk pengolahan ikan tuna di PT PMJ ialah Big eye dan Yellow fin tuna. PT PMJ mendapatkan bahan baku dari PT Charly Wijaya Tuna. Bahan Baku yang didapatkan dari PT Charly Wijaya Tuna dalam bentuk Frozen.

\section{Ketersediaan Bahan Baku}

Biaya Pemesanan

Biaya pemesanan PT. Permata Marindo Jaya periode bulan Agustus 2016 sampai bulan Juli 2017 dapat dilihat pada Tabel 1. Tabel 1 menunjukan bahwa biaya yang dibutuhkan untuk pemesanan bahan baku tidak sama setiap bulannya, ini disebabkan oleh perbedaan jumlah bahan baku yang dipesan. Biaya pemesanan meliputi gaji karyawan, transportasi, listrik, dan kebutuhan lainnya seperti biaya pembelian untuk packing hasil olahan jadi. Dengan perhitungan tersendiri didapatkan hasil bahwa untuk satu kilogram bahan baku rata-rata perusahaan mengeluarkan Rp. 1.646,- biaya pemesanan. 
Tabel 1. Jumlah Pembelian dan Biaya Pemesanan

Pembelian dalam Satu

Tahun Jumlah Bahan Baku (Kg) Biaya Pemesanan (Rp)

\begin{tabular}{lccr}
\hline Aug-16 & 65.943 & 154.300 .000 \\
\hline Sep-16 & 147.970 & 154.300 .000 \\
\hline Oct-16 & 138.998 & 154.300 .000 \\
\hline Nov-16 & 97.320 & 154.300 .000 \\
\hline Dec-16 & Jan-17 & 126.109 & 154.300 .000 \\
\hline Feb-17 & & 57.986 & 154.300 .000 \\
\hline Mar-17 & & 41.605 & 154.300 .000 \\
\hline Apr-17 & & 213.758 & 154.300 .000 \\
\hline May-17 & Jun-17 & 7.375 & 154.300 .000 \\
\hline & Jul-17 & 27.116 & 154.300 .000 \\
\hline & Total & 70.205 & 154.300 .000 \\
\hline & 118.377 & 154.300 .000 \\
\hline & $\mathbf{1 . 1 1 2 . 7 6 2}$ & $\mathbf{1 . 8 5 1 . 6 0 0 . 0 0 0}$ \\
\hline
\end{tabular}

Biaya Penyimpanan

Biaya Penyimpanan merupakan pengeluaran tetap perusahaan untuk menjaga stok bahan baku sebelum digunakan yang meliputi gaji karyawan, listrik, operasional alat penyimpanan. Biaya penyimpanan pada PT PMJ merupakan pengeluaran tetap dan tidak terpengaruh pada jumlah bahan baku yang dipesan. Pengeluaran yang dibutuhkan perusahaan untuk penyimpanan bahan baku dapat dilihat pada Tabel 2. Dalam perhitungan rata-rata pengeluaran untuk penyimpanan bahan baku didapatkan nilai sebesar Rp. 291,-per kg bahan baku baik tuna beku maupun tuna segar. 
Tabel 2. Biaya Penyimpanan Bahan Baku

\begin{tabular}{|c|c|c|}
\hline Bulan & Jumlah Bahan Baku (Kg) & Biaya Penyimpanan (Rp) \\
\hline Aug- 16 & 65,943 & $27,000,000$ \\
\hline Sep- 16 & 147,970 & $27,000,000$ \\
\hline Oct-16 & 138,998 & $27,000,000$ \\
\hline Nov- 16 & 97,320 & $27,000,000$ \\
\hline Dec- 16 & 126,109 & $27,000,000$ \\
\hline Jan-17 & 57,986 & $27,000,000$ \\
\hline Feb- 17 & 41,605 & $27,000,000$ \\
\hline Mar- 17 & 213,758 & $27,000,000$ \\
\hline Apr-17 & 7,375 & $27,000,000$ \\
\hline May-17 & 27,116 & $27,000,000$ \\
\hline Jun-17 & 70,205 & $27,000,000$ \\
\hline Jul-17 & 118,377 & $27,000,000$ \\
\hline Jumlah & $1,112,762$ & $324,000,000$ \\
\hline Rata-rata & 92,730 & $27,000,000$ \\
\hline
\end{tabular}

Biaya Persediaan

Biaya persediaan merupakan jumlah semua pengeluaran dalam proses pengadaan pemesanan dan penyimpanan bahan baku. Biaya persediaan yang dikeluarkan PT PMJ dalam pengendalian bahan baku rata-rata Rp. 1.938,- untuk setiap kg bahan baku yang dibutuhkan. Detail biaya persediaan ini dapat dilihat pada Tabel 3. Permintaan tertinggi produk olahan hasil produksi PT PMJ setiap tahunnya adalah pada olahan tuna Permintaan olahan hasil saku dengan nilai $358.133 \mathrm{~kg} / \mathrm{tahun}$ dan permintaan terendah adalahh olahan tuna chunk dengan nilai produksi $119.378 \mathrm{~kg} / \mathrm{tahun}$.

Tabel 3. Biaya Persediaan 


\begin{tabular}{|c|r|r|r|}
\hline Persediaan dalam Satu Tahun & Biaya Pemesanan (Rp) & Biaya Penyimpanan (Rp) & Biaya Persediaan (Rp) \\
\hline Agust-16 & 154.300 .000 & 27.000 .000 & 181.300 .000 \\
\hline Sep-16 & 153.300 .000 & 27.000 .000 & 180.300 .000 \\
\hline Okt-16 & 152.550 .000 & 27.000 .000 & 179.550 .000 \\
\hline Nop-16 & 152.550 .000 & 27.000 .000 & 179.550 .000 \\
\hline Des-16 & 152.550 .000 & 27.000 .000 & 179.550 .000 \\
\hline Jan-17 & 153.050 .000 & 27.000 .000 & 180.050 .000 \\
\hline Feb-17 & 152.800 .000 & 27.000 .000 & 179.800 .000 \\
\hline Mar-17 & 151.800 .000 & 27.000 .000 & 178.800 .000 \\
\hline Apr-17 & 151.800 .000 & 27.000 .000 & 178.800 .000 \\
\hline Mei-17 & 152.300 .000 & 27.000 .000 & 179.300 .000 \\
\hline Jun-17 & 152.550 .000 & 27.000 .000 & 179.550 .000 \\
\hline Jul-17 & 152.550 .000 & 27.000 .000 & 179.550 .000 \\
\hline Total & $\mathbf{1 . 8 3 2 . 1 0 0 . 0 0 0}$ & $\mathbf{3 2 4 . 0 0 0 . 0 0 0}$ & $\mathbf{2 . 1 5 6 . 1 0 0 . 0 0 0}$ \\
\hline Rata-rata & $\mathbf{1 5 2 . 6 7 5 . 0 0 0}$ & $\mathbf{2 7 . 0 0 0 . 0 0 0}$ & $\mathbf{1 7 9 . 6 7 5 . 0 0 0}$ \\
\hline
\end{tabular}

\section{Tingkat Permintaan Konsumen}

PT PMJ melakukan produksi pada umumnya untuk memenuhi permintaan konsumen. Adapun olahan hasil produksi yang dilakukan oleh PT PMJ berupa tuna saku, tuna steak, tuna loin, tuna cube, dan tuna chunk Tabel 4. Hasil Olahan Produksi

\begin{tabular}{|c|r|}
\hline Produk Olahan & Hasil Produksi (kg/tahun) \\
\hline Saku & 358.133 \\
\hline Steak & 298.445 \\
\hline Loin & 238.755 \\
\hline Cube & 179.067 \\
\hline Chunk & 119.378 \\
\hline Total & $\mathbf{1 . 1 9 3 . 7 7 8}$ \\
\hline
\end{tabular}

Metode Economic Order Quantity

Berdasarkan perhitungan dengan metode EOQ dalam pengadaan bahan baku, diperoleh total biaya yang ekonomis dalam pengadaan bahan baku. Hasil perhitungan metode pengendalian bahan baku menggunakan metode EOQ dapat dibandingkan dengan metode yang digunakan oleh PT PMJ dengan hasil seperti pada Tabel 5 berikut.

\begin{tabular}{|c|r|}
\hline Hasil Perhitungan EOQ & Jumlah Bahan Baku (Kg) \\
\hline $\mathrm{Q}$ & 1.112 .762 \\
\hline $\mathrm{Q}^{*}$ & 1.080 .572 \\
\hline $\mathrm{n}^{*}$ & 1,03 \\
\hline $\mathrm{I}$ & 291 \\
\hline Persediaan rata-rata & 540.286 \\
\hline Biaya Pemesanan Tahunan (Rp) & 157.223 .154 \\
\hline
\end{tabular}




\begin{tabular}{|c|r|}
\hline Biaya Penyimpanan Tahunan $(\mathrm{Rp})$ & 145.877 .220 \\
\hline Biaya Pembelian $(\mathrm{Rp})$ & 41.061 .736 .000 \\
\hline Total Biaya Persediaan (Rp) & 41.364 .836 .374 \\
\hline
\end{tabular}

Pada Tabel 5 dijelaskan bahwa biaya persediaan bahan baku ikan tuna PT PMJ yang optimal menurut metode EOQ adalah sebesar Rp. 41.364.836.374. Tabel 6 memperlihatkan bahwa perbandingan selisih total permintaan bahan baku metode yang dipakai perusahaan dengan total permintaan metode EOQ.

Tabel 6. Perbandingan Total Permintaan Metode EOQ dengan Metode Perusahaan

\begin{tabular}{|c|c|c|c|c|}
\hline \multirow{2}{*}{ Bulan } & Perminta & & \multirow{2}{*}{ Selisih } & \multirow{2}{*}{ Persentase } \\
\hline & \multicolumn{2}{|c|}{ Metode Perusahaan Metode EOQ } & & \\
\hline Aug-16 & 65.943 & 67.921 & 1.978 & $3 \%$ \\
\hline Sep-16 & 147.970 & 152.409 & 4.439 & $3 \%$ \\
\hline Oct-16 & 138.998 & 143.168 & 4.170 & $3 \%$ \\
\hline Nov-16 & 97.320 & 100.240 & 2.920 & $3 \%$ \\
\hline Dec-16 & 126.109 & 129.892 & 3.783 & $3 \%$ \\
\hline Jan-17 & 57.986 & 59.726 & 1.740 & $3 \%$ \\
\hline Feb-17 & 41.605 & 42.853 & 1.248 & $3 \%$ \\
\hline Mar-17 & 213.758 & 220.171 & 6.413 & $3 \%$ \\
\hline Apr-17 & 7.375 & 7.596 & 221 & $3 \%$ \\
\hline May-17 & 27.116 & 27.929 & 813 & $3 \%$ \\
\hline Jun-17 & 70.205 & 72.311 & 2.106 & $3 \%$ \\
\hline Jul-17 & 118.377 & 121.928 & 3.551 & $3 \%$ \\
\hline TOTAL & 1.112 .762 & 1.080 .572 & 32.190 & $3 \%$ \\
\hline
\end{tabular}

Metode perusahaan menggunakan penghitungan secara manual dengan menghitung total permintaan sebesar $1.112 .762 \mathrm{~kg}$ bahan baku frozen Penghitungan dengan menggunakan metode EOQ ialah $1.080 .572 \mathrm{~kg}$ bahan baku. Selisih perbandingan yang didapatkan dari dua metode tersebut untuk permintaan bahan baku penghitungan biaya persediaan dengan cara pengitungan secara manual dengan mengeluarkan biaya seperti, Biaya total pembelian bahan baku, biaya pemesanan, biaya penyimpanan, dan biaya persediaan. Rp. 42.284.956.000 untuk biaya total pembelian, Rp. 1.832.100.000 untuk biaya pemesanan, Rp. 324. 000.000 untuk biaya penyimpanan, Rp. sebesar $32.190 \mathrm{~kg}$ dengan persentase sebesar 3\%. Artinya perusahaan dapat menambah permintaan untuk bahan baku perusahaan. Perusahaan juga mempunyai kapasitas cold storage sebanyak 5 unit yang masing-masing berkapasitas 3000 ton, dengan ini perusahaan masih dapat menampung bahan baku sebanyak $32.190 \mathrm{~kg}$. 
Tabel 7. Perbandingan Total Persediaan Metode EOQ dengan Metode Perusahaan

\begin{tabular}{|c|r|r|r|}
\multicolumn{5}{|c|}{ TOTAL BIAYA PERSEDIAAN $(\mathrm{Rp} / \mathrm{Th})$} \\
\hline BIAYA & METODE PERUSAHAAN & METODE EOQ & \multicolumn{1}{c|}{ SELISIH } \\
\hline Pemesanan & 1.832 .100 .000 & 163.297 .513 & 1.668 .802 .487 \\
\hline Peirimpanan & 324.000 .000 & 151.288 .281 & 172.711 .719 \\
\hline Bahan Bahn & 42.284 .956 .000 & 41.061 .736 .000 & 1.223 .220 .000 \\
\hline Persediann & 2.156 .100 .000 & 2.094 .148 .536 & 2.156 .100 .000 \\
\hline TOTAL & 46.597 .156 .000 & 43.470 .470 .330 & 3.126 .685 .670 \\
\hline
\end{tabular}

Tabel 7 memperlihatkan perbandingan total biaya persediaan yang digunakan perusahaan dengan metode EOQ. Metode yang digunakan oleh perusahaan terkait 2.156.100.000 untuk biaya persediaan, dalam hal ini akumulasi biaya dari metode yang digunakan oleh perusahaan senilai Rp. 46.597.1556.000. Hasil menggunakan metode EOQ didapatkan nilai sebesar Rp. 43.470.470.330, perbandingan selisih yang didapatkan dari dua metode ini untuk biaya persediaan sebesar Rp. 3.126.685.670,- dengan persentase 7\%. Artinya perusahaan dapat meminimalkan biaya persediaan jika menggunakan perhitungan dengan metode EOQ.

Hasil analisis perbandingan biaya persediaan dan biaya pembelian bahan baku serta penghematan, maka dapat direkomendasikan suatu metode alternatif pengendalian persediaan bahan baku ikan tuna PT PMJ. Metode alternatif ini diharapkan dapat menghemat biaya perusahaan, melalui penghematan biaya persediaan bahan baku yang terdiri dari biaya pemesanan dan biaya penyimpanan bahan baku serta melalui penghematan biaya pembelian bahan baku. Hasil analisis perbandingan biaya persediaan dan penghematan metode economic order quantity terhadap kebijakan perusahaan periode agustus 2016 sampai dengan Juli 2017, menunjukan bahwa kebijakan pengendalian persediaan ikan tuna belum efisien, artinya biaya persediaan masih dapat ditekan lebih rendah.

\section{KESIMPULAN}

1. PT PMJ menggunakan jenis bahan baku tuna Big eye dan Yellow fin. PT PMJ mendapatkan bahan baku dari PT Charly Wijaya Tuna. Bahan Baku yang didapatkan dari PT Charly Wijaya Tuna dalam bentuk Frozen. 
2. Berdasarkan perhitungan pada pembahasan sebelumnya, perusahaan mampu menambah ketersediaan bahan baku sebesar $32.190 \mathrm{~kg}$ per tahun atau perusahaan dapat menghemat total biaya persediaan sebesar Rp. 3.126.685.670,- jika menggunakan metode EOQ untuk mengendalikan persediaan. Total biaya persediaan dengan metode Economic Order Quantity $(E O Q)$ lebih efisien dibandingkan dengan metode yang digunakan PT. PMJ.

\section{DAFTAR PUSTAKA}

Adawyah, R. 2007. Pengolahan dan Pengawetan sementara Ikan. Bumi Aksara. Jakarta.

Assauri, S. 2004. Manajemen Produksi dan Operasi (Edisi Revisi). Jakarta (ID): Universitas Indonesia.

Badan Standarisasi Nasional. 2006. Penanganan dan Pengolahan Produk Tuna. SNI 01-4485.32006. Direktorat Jenderal Perikanan. Jakarta.

Bahagia, N. 2006 dalam Absor Y.N 2015. Sistem Inventory. Institut Tekhnologi Bandung.

Dahuri, R., Rais Y., Putra S., G., Sitepu, M.J. 2001. Pengelolaan Sumber daya Wilayah Pesisir dan Lautan Secara Terpadu PT. Pradnya Paramita, Jakarta.

Divianto. 2011. Faktor-faktor yang Mempengaruhi Perusahaan dalam Melakukan Auditor Switch. Jurnal Ekonomi dan Informasi Akuntansi.

Gasperzs, V. 1992. Analisis Sistem Terapan. Penerbit Transito Bandung, Bandung.

Handoko, T. 1999. Dasar-dasar Manajemen Produksi dan Operasi. UNS PRESS. Surakarta. Heizer, J. dan Render, B. 2001. Manajemen Operasi (Terjemahan): Salemba Empat. Jakarta Maulana, H. 2012. Analisis Bahaya dan penentuan Titik Pengendalian Kritis pada Penanganan Tuna Segar Utuh di Bali Ocean Anugrah Linger Indonesia Benoa-Bali. Skripsi. Moeljanto. 1992. Pengawetan dan Pengolahan Hasil Perikanan, Jakarta: Penebar Swadaya. 